УДК 338.4:338.24

DOI: https://doi.org/10.37320/2415-3583/15.16

Скоробогатова Н.С.

кандидат економічних наук, доцент Національний технічний університет Украӥни «Київський політехнічний інститут імені Ігоря Сікорського» ORCID: https://orcid.org/0000-0002-2741-7629

\title{
ОЦІНЮВАННЯ СТІЙКОСТІ РОЗВИТКУ ПІДПРИЕМСТВ В УМОВАХ ЕКОНОМІЧНОЇ НЕСТАБІЛЬНОСТІ
}

У статті здійснено аналіз теоретичних підходів до визначення сутності стійкого розвитку економічних суб'єктів, виокремлено сутнісні ознаки стійкого розвитку. Виокремлено принщипові відмінності між теоретичними поняття сталий та стійкий розвиток. Проаналізовано динаміку зміни структури активів вітчизняних підприємств з виокремленням особливостей їх формування у великих, середніх та малих підприємствах. На основі аналізу статистичних даних щьоо джерел формування господарських засобів підприємств протягом 2013-2019 років визначено диспропориіі, щзо негативно позначаються на ефективності їх діяльності. Зокрема, високий ступінь залежності підприємств від зовнішніх джерел фінансування призводить до стійкої тендениї зменшення та нестачі робочого капіталу для підтримки стійкого розвитку на довгострокову перспективу. Водночас, доведено парадокс функиіонування вітчизняного бізнесу, який за умови недостатності робочого капіталу демонструє зростання рівня рентабельності як операційної, так і всієї діяльності. Кореляційний аналіз статистичних даних підтвердив наявність прямого зв'язку між обсягами капітальних інвестицій підприємств та рівнем їх рентабельності, проте виявив зворотну залежність між обсягами робочого капіталу та капітальними інвестиціями. Виявлені залежності дозволили сформувати тезу про наявність системної проблеми в управлінні підприсмствами - незбалансованість управління дебіторською та кредиторською заборгованостями, щзо в умовах нестабільної економіки, може призвести до загальної кризи через масову неплатоспроможність підприємств. 3 метою запобігання такої ситуації запропоновано низку заходів щчодо забезпечення стійкого розвитку підприємств за рахунок управління їх кредиторською та дебіторською заборгованостями.

Ключові слова: стійкий розвиток, економічна нестабільність, рентабельність, інвестицї, прибуток, платоспроможність.

Постановка проблеми. Економічний добробут суспільства забезпечується збалансованою діяльністю всіх економічних суб'єктів. У сучасних умовах господарювання спостерігається високий ступінь ризику та невизначеності, що призводить до економічної нестабільності та соціальних диспропорцій у суспільстві. Одним з визначальних суб'єктів, що виготовляє економічні блага задля задоволення потреб, є підприємства. Тому невідкладним завданням держави є забезпечення їх стійкого розвитку та створення сприятливих умов для цього із дотриманням положень концепції сталого розвитку та з врахуванням вимог сучасного індустріального укладу. Статистичні дані свідчать про наявність системних проблем у функціонуванні вітчизняного підприємницького сектору, що негативно позначається як на податкових надходженням до бюджету, так і на створенні робочих місць та забезпеченні добробуту населення в цілому. Окрім того, економічна, політична, соціальна нестабільність, які спостерігаються як на макрорівні, так i на міжнародному рівні, негативно впливають на розвиток національного виробництва. Вважаємо, що ідентифікація факторів, що формують та забезпечують стійкий розвиток підприємств в даних умовах, дозволить врахувати їх при розробці стратегії розвитку підприємств та політики управління їх активами та зобов'язаннями з метою підвищення ефективності діяльності та мінімізації рівня загроз.

Аналіз останніх досліджень і публікацій. Проблемам сталого розвитку суспільства, визначення методології оцінювання інтегрального показника сталого розвитку присвячено багато робіт вітчизняних та зарубіжних науковців, зокрема роботи науковців Світового центру даних з геоінформатики та сталого розвитку [2], Бурик 3. [4], Бурда А. [3], Тодорюк С. [9], Торкатюк В., Бібік Н. [10] та інші. Науковці визначили концептуальні засади формування теорії сталого розвитку суспільства в цілому та окремих територіальних одиниць зокрема. Проте поза увагою залишились питання оцінювання сталого розвитку на мікрорівні. Сутність та особливості оцінювання стійкого розвитку підприємств розкрито у роботах [5; 9] та напрацюваннях інших фахівців. Водночас, наявні теоретичні підходи не враховують особливості формування та забезпечення стійкого розвитку підприємств в реаліях української економіки. Також недостатньо дослідженими залишились питання визначення факторів стійкого розвитку підприємств в умовах економічної нестабільності, що є особливо актуальним на даний час.

Метою статті $\epsilon$ розвиток науково-методичних засад формування моделі стійкого збалансованого розвитку підприємств в умовах економічної нестабільності. Для досягнення даної мети було поставлено та вирішено наступні завдання: ідентифікація якісних ознак понять стійкий та сталий розвиток; виявлення закономірностей розвитку вітчизняних підприємств на основі аналізу статистичних даних та визначення основних факторів, що становлять загрозу їх стійкому розвитку в умовах економічної нестабільності; надання рекомендацій щодо забезпечення стійкого розвитку підприємств за рахунок управління їх кредиторською та дебіторською заборгованостями. 
Виклад основного матеріалу. Аналіз літературних джерел виявив наявність неоднозначних підходів щодо трактування сутності понять сталий та стійкий розвиток. Узагальнення теоретичних підходів, представлених у роботах Бурик 3. М. [4], Бурди А. I. [3], Тодорюк С. І. [9], Торкютюк В. І., Бібік Н. В. [10], колективу акторів під керівництвом Згуровського М. 3. [2] та закордонним фахівцям у сфері сталого розвитку суспільства [1], дозволяє дійти висновку, що в основі концепції сталого розвитку лежить встановлення балансу між задоволенням сучасних потреб суспільства та захистом інтересів майбутніх поколінь, включаючи взаємоузгоджений розвиток у трьох напрямках: економічний, соціальний та екологічний. Стійкий розвиток також прирівнюється науковцями [5] зі сталим за своїми ознаками (економічні, соціальні, екологічні аспекти), проте вважаємо, що дане поняття доречним є до використання у більш вузькому тлумаченні, а саме: постійний розвиток господарської системи, що заснований на зростаючій динаміці отримуваних результатів при ефективному залученні ресурсів задля цього. 3 метою визначення закономірностей розвитку вітчиз- няних підприємств задля забезпечення їх стійкого розвитку саме у такому визначенні було проаналізовано статистичні дані, що характеризують результати їх діяльності. Зокрема, за даними Державної служби статистики України побудовано графіки 3 динамікою рентабельності підприємств у розрізі за розмірами їх активів та масштабами діяльності (рис. 1, 2).

Як видно з рис. 1, 2, після різкого падіння рентабельності як операційної, так і всієї діяльності підприємств у 2014 році, починаючи з 2015 року відбувається поступове відновлення та навіть підвищення рівня рентабельності їх діяльності. Причому найбільший ступінь падіння відчули саме малі підприємства. Безумовно, падіння і обсягів, i ефективності діяльності підприємств у 2014 році мало відповідні підстави: початок військової агресії РФ, окупація частини територій України, порушення економічний зв'язків з постачальниками, стрімка переорієнтація на нові ринки збуту тощо. Підвищення значення показника рентабельності як інтегрального індикатора ефективності діяльності підприємств мало б заспокоїти керівників. Зростання обсягів капітальних інвестицій протягом аналізованого періоду також позитивно позначилося на діяльності під-

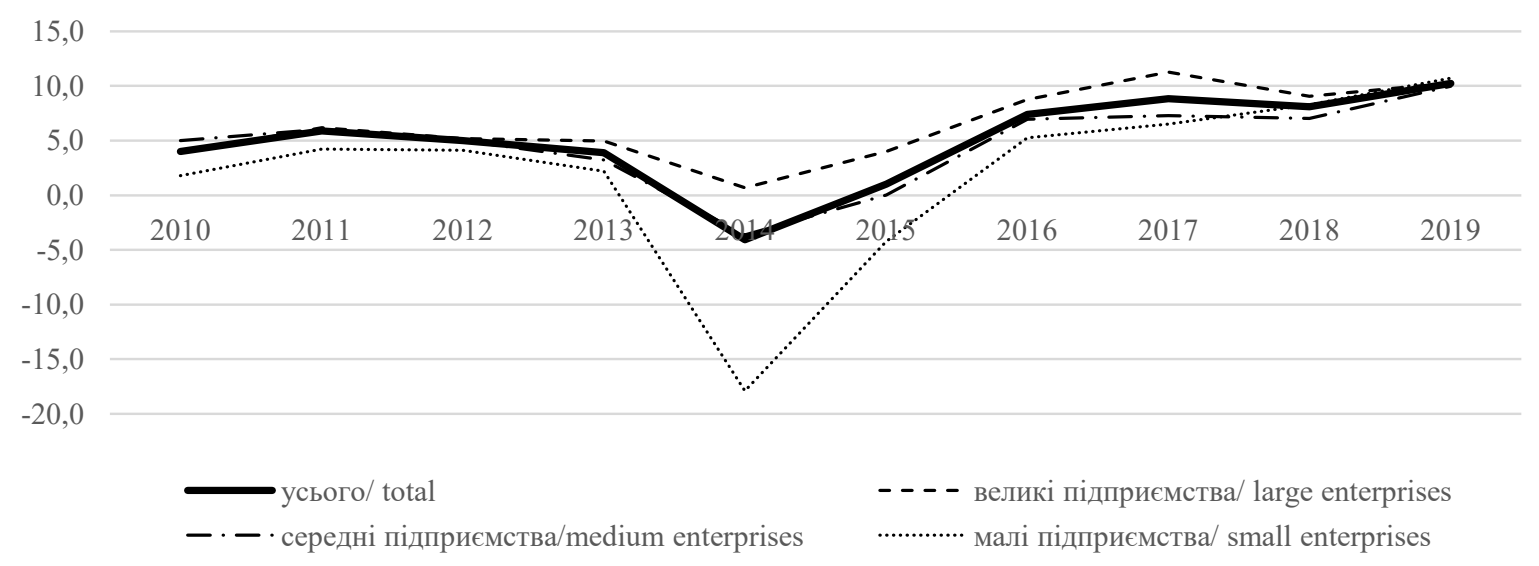

Рисунок 1 - Динаміка рентабельності (збитковості) операційної діяльності підприсмств України, 2010-2019 роки

Джерело: побудовано за даними [6]

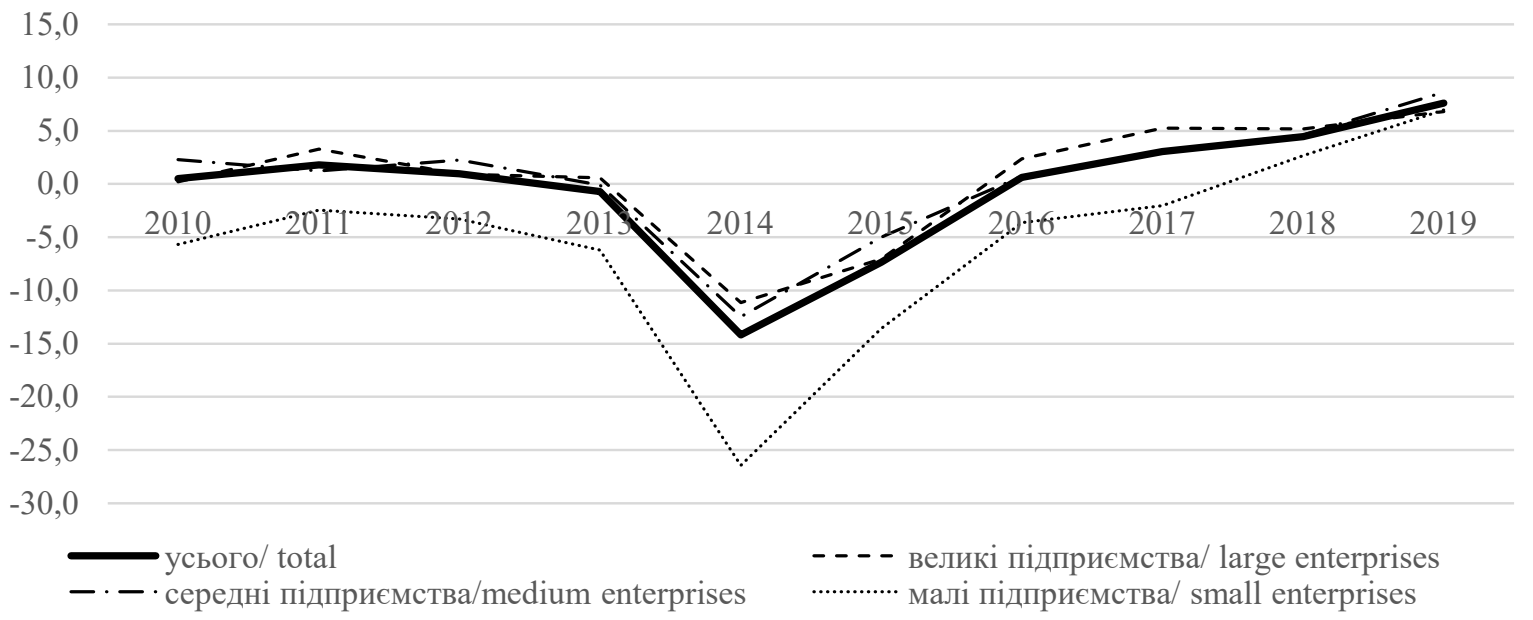

Рисунок 2 - Динаміка рентабельності (збитковості) всієї діяльності підприсмств України, 2010-2019 роки

Джерело: побудовано за даними [6] 
Таблиця 1 - Капітальні інвестиції за джерелами фінансування, 2010-2019 роки

\begin{tabular}{|l|c|c|c|c|c|c|c|c|c|c|}
\hline & $\mathbf{2 0 1 0}$ & $\mathbf{2 0 1 1}$ & $\mathbf{2 0 1 2}$ & $\mathbf{2 0 1 3}$ & $\mathbf{2 0 1 4}$ & $\mathbf{2 0 1 5}$ & $\mathbf{2 0 1 6}$ & $\mathbf{2 0 1 7}$ & $\mathbf{2 0 1 8}$ & $\mathbf{2 0 1 9}$ \\
\hline Усього & $\mathbf{1 8 0 5 7 5 , 5}$ & $\mathbf{2 4 1 2 8 6 , 0}$ & $\mathbf{2 7 3 2 5 6 , 0}$ & $\mathbf{2 4 9 8 7 3 , 4}$ & $\mathbf{2 1 9 4 1 9 , 9}$ & $\mathbf{2 7 3 1 1 6 , 4}$ & $\mathbf{3 5 9 2 1 6 , 1}$ & $\mathbf{4 4 8 4 6 1 , 5}$ & $\mathbf{5 7 8 7 2 6 , 4}$ & $\mathbf{6 2 3 9 7 8 , 9}$ \\
\hline у т.ч. за рахунок & & & & & & & & & & \\
\hline $\begin{array}{l}\text { коштів } \\
\text { державного } \\
\text { бюджету }\end{array}$ & 10223,3 & 17376,7 & 16288,3 & 6174,9 & 2738,7 & 6919,5 & 9264,1 & 15295,2 & 22814,1 & 30834,5 \\
\hline $\begin{array}{l}\text { коштів місцевих } \\
\text { бюджетів }\end{array}$ & 5730,8 & 7746,9 & 8555,7 & 6796,8 & 5918,2 & 14260,0 & 26817,1 & 41565,5 & 50355,5 & 56480,0 \\
\hline $\begin{array}{l}\text { власних коштів } \\
\text { підприємств та } \\
\text { організацій }\end{array}$ & 111371,0 & 147569,6 & 171176,6 & 165786,7 & 154629,5 & 184351,3 & 248769,4 & 310061,7 & 409585,5 & 408275,7 \\
\hline $\begin{array}{l}\text { кредитів банків } \\
\text { та інших позик }\end{array}$ & 22888,1 & 36651,9 & 39724,7 & 34734,7 & 21739,3 & 20740,1 & 27106,0 & 29588,9 & 44825,4 & 67232,6 \\
\hline $\begin{array}{l}\text { коштів } \\
\text { інвесторів- } \\
\text { нерезидентів }\end{array}$ & 3723,9 & 5038,9 & 4904,3 & 4271,3 & 5639,8 & 8185,4 & 9831,4 & 6206,4 & 1795,5 & 4663,9 \\
\hline $\begin{array}{l}\text { коштів населення } \\
\text { на будівництво } \\
\text { житла }\end{array}$ & 18885,9 & 17589,2 & 22575,5 & 24072,3 & 22064,2 & 31985,4 & 29932,6 & 32802,5 & 34645,7 & 32422,0 \\
\hline $\begin{array}{l}\text { інших джерел } \\
\text { фінансування }\end{array}$ & 7752,5 & 9312,8 & 10030,9 & 8036,7 & 6690,2 & 6674,7 & 7495,5 & 12941,3 & 14704,7 & 24070,2 \\
\hline
\end{tabular}

Джерело: побудовано за даними [6]

приємств (табл. 1). Зокрема, кореляційний аналіз це підтверджує, оскільки коефіцієнт кореляції між обсягом капітальних інвестицій та рівнем рентабельності операційної діяльності становить 0,7204, а капітальними інвестиціями та рентабельністю всієї діяльності трохи менше, проте все одно наявних взаємозв'язок Ккор $=0,6385$.

Структурний аналіз (рис. 3) свідчить про те, що підприємства більшою мірою вкладають кошти у матеріальні активи, частина капітальних інвестицій поступово зростає (з 4,4\% у 2010 році до 7,2\% у 2019 році), проте за рахунок зростання інвестицій у концесії, патенти, ліцензії, торговельні марки та аналогічні права.

У ході дослідження було також проаналізовано зміни структури активів та пасивів підприємств у розрізі великі, середні та малі (рис. 4, 5). Вважаємо, що саме структура господарських засобів підприємств (активи) та джерел їх формування (пасиви) дозволить виявити закономірності формування фінансових результатів.

Як свідчать отримані результати, у структурі активів підприємств переважають, як правило оборотні активи. Лише у групі великих підприємств більшу питому вагу становлять необоротні активи, що пояснюється наявністю більшою мірою застарілими виробничими потужностями, що були отримані у спадщину під час приватизації підприємств. Водночас, середні та малі підприємства мають майже не помітну на графіку, але більшу ніж великі підприємства, частину необоротних активів та груп вибуття, утримуваних для продажу. Така ситуація свідчить про можливі рішення власників підприємств позбутися частини необоротних активів протягом короткого періоду часу. Що стосується пасивів, то аналіз статистичної інформації (рис. 5) показує високий ступінь залежності підприємств від запозичень, зокрема поточних зобов'язань. Особливо відчутною залежність від зовнішніх запозичень $є$ для середніх та малих підприємств. Яскраво ілюструє проблему нестачі робочого капіталу рис. 6 .

Як видно з рис. 6 , суцільна нестача робочого капіталу починається з 2015 року, тобто існує часовий лаг між падінням рентабельності (рис. 1,2 ) та нестачею

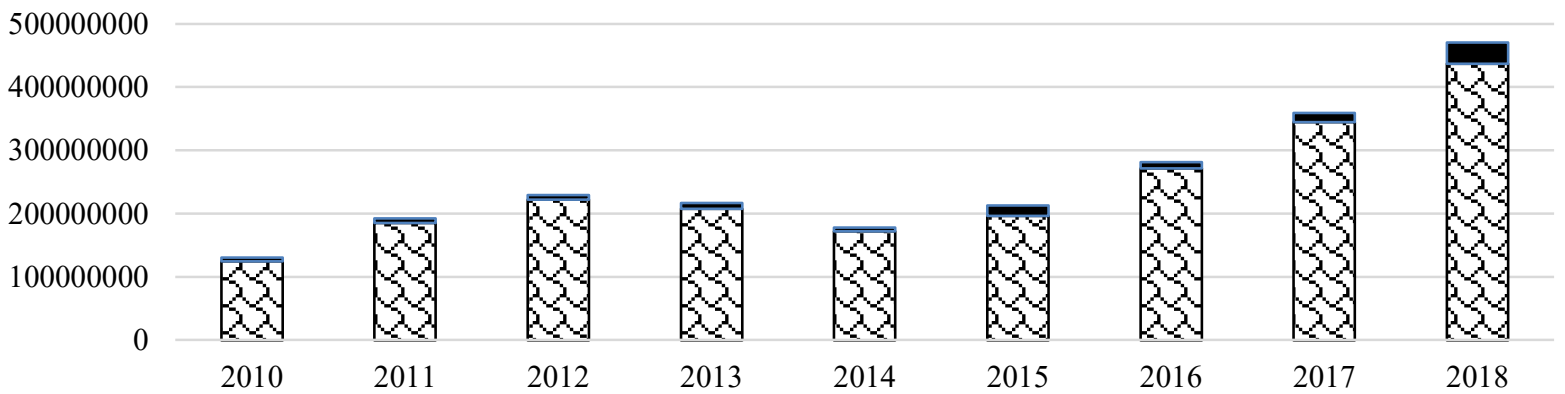

— Капітальні інвестиції у нематеріальні активи, тис. грн

■Капітальні інвестиції у матеріальні активи, тис. грн

Рисунок 3 - Динаміка капітальних інвестицій, 2010-2019 роки 


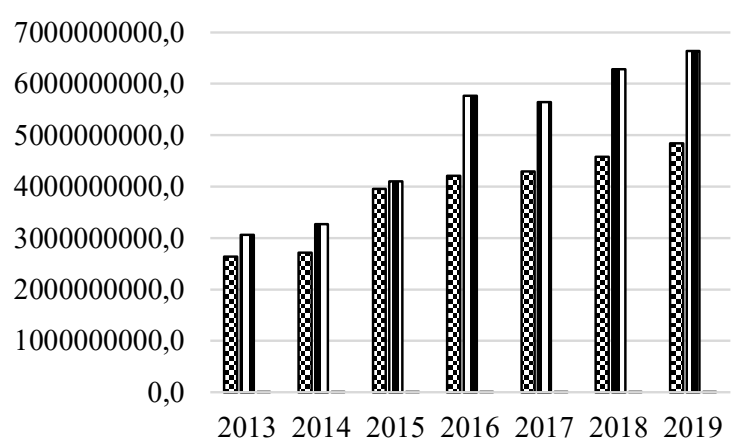

$\mathbf{0}$ необоротні активи/non-negotiable assets

Dоборотні активи/ current assets

- необоротні активи та гупи вибуття/ non-negotiable assets and groups of leaving

\section{а) всі підприємства}

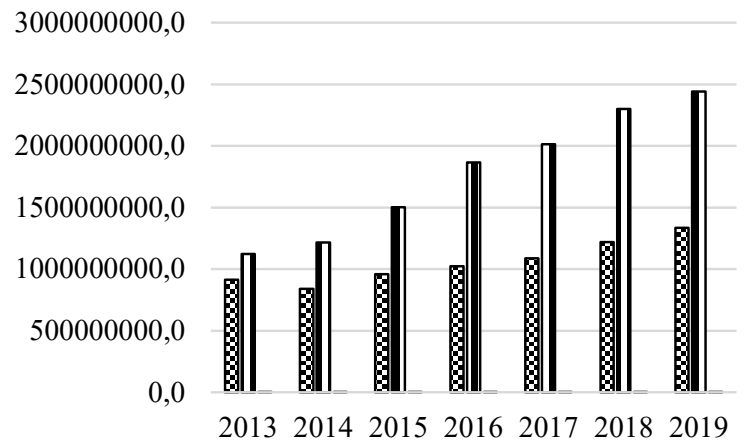

$\mathbf{0}$ необоротні активи/non-negotiable assets

Dоборотні активи/ current assets

- необоротні активи та гупи вибуття/ non-negotiable assets and groups of leaving

\section{в) середні підприємства}

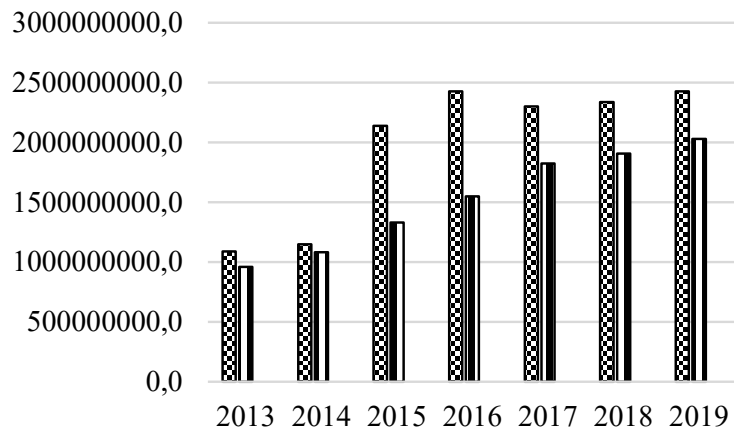

$\mathbf{0}$ необоротні активи/non-negotiable assets

Шоборотні активи/ current assets

- необоротні активи та гупи вибуття/ non-negotiable assets and groups of leaving

\section{б) великі підприємства}

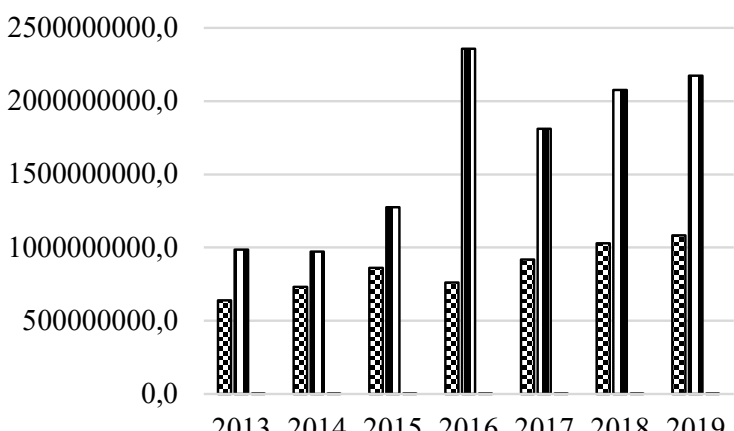

$\mathbf{\sigma}$ необоротні активи/non-negotiable assets

Dоборотні активи/ current assets

- необоротні активи та гупи вибуття/ non-negotiable assets and groups of leaving

\section{г) малі підприємства}

Рисунок 4 - Структура активів підприсмств України, 2013-2019 роки

Джерело: побудовано за даними [6]

робочого капіталу, який є одним 3 ключових факторів стійкого розвитку підприємств. Головною метою управління капіталом $є$ забезпечення балансу між рентабельністю та платоспроможністю підприємства. Саме керівництво підприємства визначає розмір оборотного (або робочого) капіталу, що необхідний для забезпечення діяльності підприємства та подальшого його розвитку. Від'ємне значення даного показника, яке спостерігається для всіх вітчизняних підприємств, починаючи з 2015 року, свідчить про те, що вони працюють у борг та не здатні погасити свої короткострокові зобов'язання за рахунок оборотних активів. Особливо відчутною дана проблема $\epsilon$ для середніх підприємств (рис. 6). Кореляційний аналіз свідчить про наявність зворотного зв'язку між рівнем рентабельності операційної діяльності та розміром робочого капіталу в цілому для всіх підприємств Ккор =-0,8742 (для великих підприємств Ккор =-0,658, для середніх Ккор = -0,6836). Оскільки рентабельність всієї діяльності підприємства враховує результати не лише від основної, але й від інших видів діяльності, то ступінь кореляції між даним видом рентабельності та робочим капіталом $є$ трохи меншою, але такою зворотною (в цілому по Україні Ккор $=-0,4514$, а для середніх підприємств Ккор = -0,6949). Натомість малі підприємства мають менший обсяг активів, порівняно із середніми та великими, і відповідно, менший ступінь залежності від обсягів робочого капіталу (коефіцієнти кореляції для них близькі до нуля). Таким чином, проведений аналіз свідчить про високий ступінь залежності вітчизняних підприємств від наявної короткострокової заборгованості, що свідчить про високий ступінь ризику їх подальшого розвитку, особливо бізнес середнього розміру. 3 метою вирішення даною проблеми вважаємо доречним запровадити системи контролінгу, під яким розуміємо інформаційну сис- 


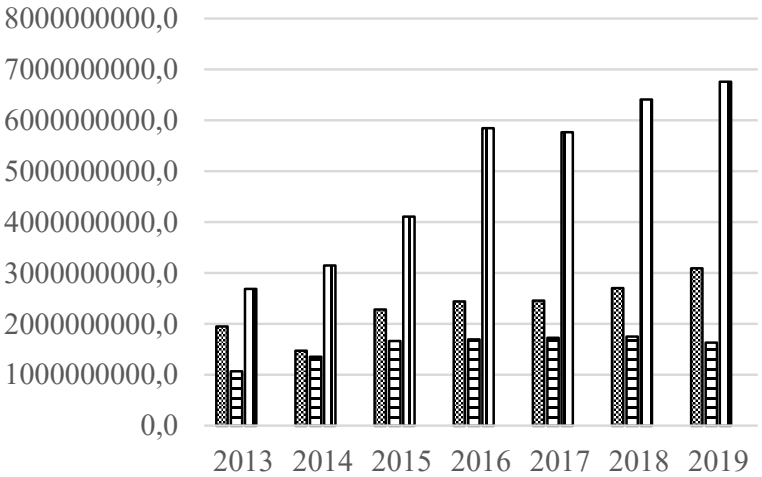

冈ласний капітал/ equity capital

曰довгострокові зобов'язання і забезпечення/ long-term commitments and provision

๑ поточні зобов'язання і забезпечення/ current liabilities and provision

— зобов'язання, пов'язані з необоротними активами/ obligations, related to the irreversible assets

\section{а) всі підприємства}

3000000000,0

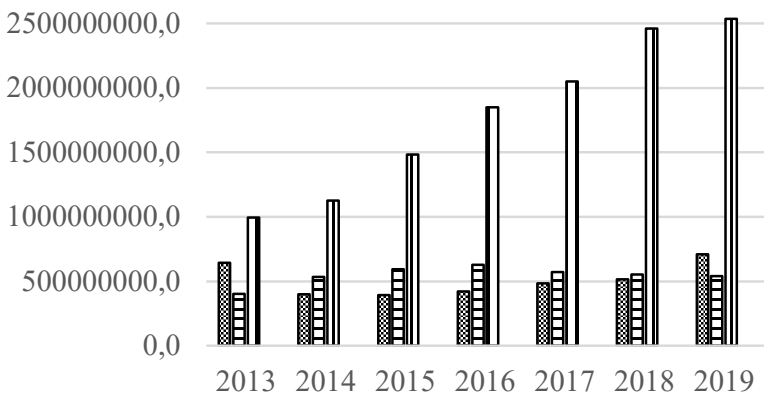

власний капітал/ equity capital

曰довгострокові зобов’язання і забезпечення/ long-term commitments and provision

口 поточні зобов'язання і забезпечення/ current liabilities and provision

— зобов'язання, пов'язані з необоротними активами/ obligations, related to the irreversible assets

\section{в) середні підприємства}

2500000000,0

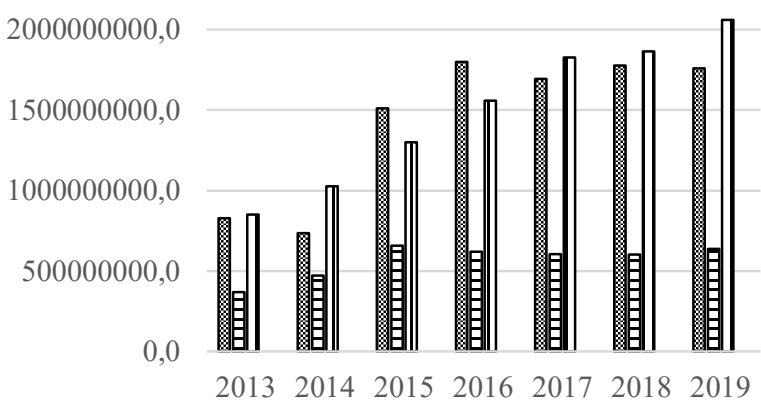

в власний капітал/ equity capital

曰довгострокові зобов’ язання і забезпечення/ long-term commitments and provision

Ф поточні зобов'язання і забезпечення/ current liabilities and provision

- зобов'язання, пов'язані з необоротними активами/ obligations, related to the irreversible assets

\section{б) великі підприємства}

3000000000,0

2000000000,0

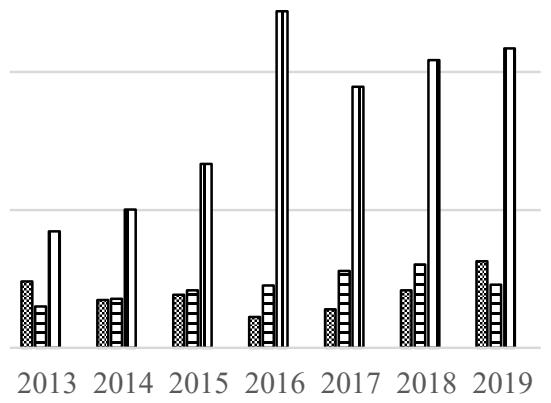

в власний капітал/ equity capital

曰довгострокові зобов'язання і забезпечення/ long-term commitments and provision

口 поточні зобов'язання і забезпечення/ current liabilities and provision

- зобов'язання, пов'язані з необоротними активами/ obligations, related to the irreversible assets

\section{г) малі підприємства}

Рисунок 5 - Структура пасивів підприємств України, 2013-2019 роки

Джерело: побудовано за даними [6]

тему, що відображає процес, набір дій, направлених на прийняття достатньо обгрунтованих рішень для управління платоспроможністю та економічним розвитком підприємства в цілому на базі інформації, що дасть можливість забезпечити конкурентоспроможність підприємства в умовах економічної нестабільності [8; 7]. Таким чином, вважаємо, що запровадження системи контролінгу грошових коштів дозволить підприємствам оптимізувати розмір робочого капіталу із забезпеченням відповідного рівня рентабельності та зменшенням ризиків у подальшому.
Висновки. В результаті проведеного дослідження ідентифіковано принципові відмінності понять сталий та стійкий розвиток, зокрема, запропоновано під стійким розвитком розуміти постійний розвиток господарської системи, що заснований на зростаючій динаміці отримуваних результатів при ефективному залученні ресурсів задля цього.

На основі аналізу статистичних та аналітичних даних великих, середніх та малих підприємств України виявлено основну загрозу стійкого розвитку підприємств в умовах економічної нестабільності - рента- 


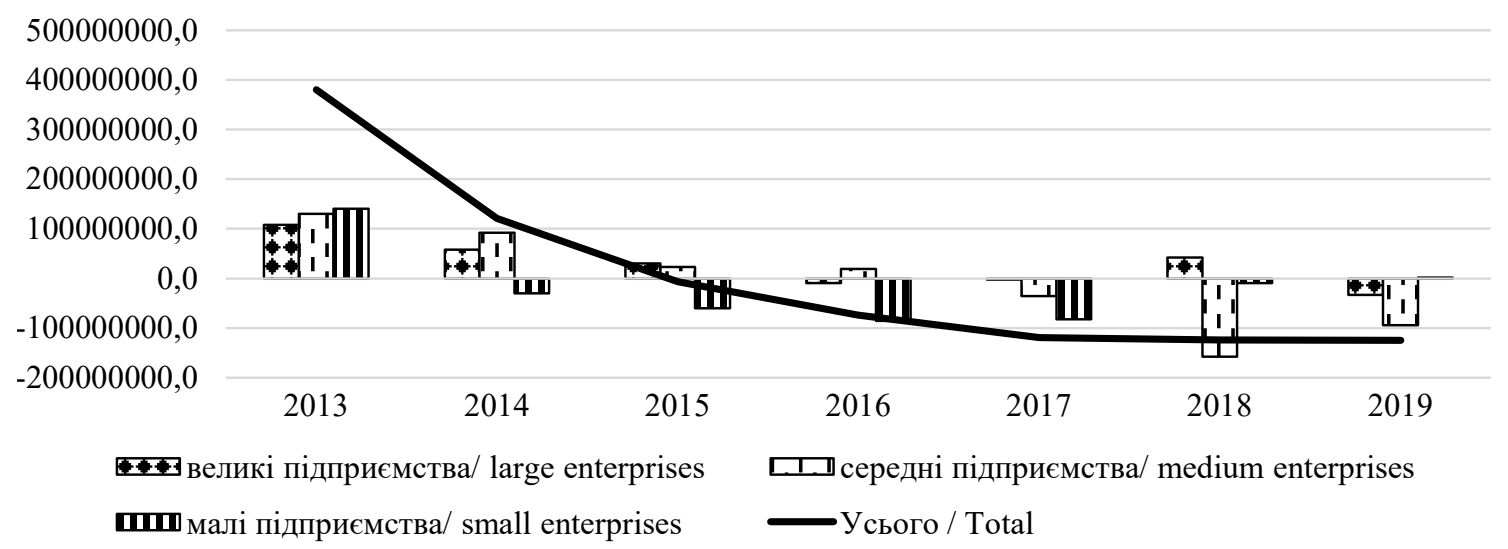

Рисунок 6 - Динаміка обсягів робочого капіталу підприємств України, 2013-2019 роки

Джерело: побудовано за даними [6]

бельна діяльність при недостатньому розмірі робочого капіталу свідчить про високий ступінь залежності від поточних зобов'язань та проблеми платоспроможності. 3 метою вирішення зазначених загроз запропоновано запровадити систему контролінгу, зокрема контролінг грошових коштів, що дозволить оптимізувати систему розрахунків з контрагентами та сприятиме забезпеченню стійкого розвитку у подальшому.

Подальшого дослідження потребує розробка інструментів запровадження системи контролінгу 3 врахуванням розмірів та галузевої специфіки підприємств.

\section{Список використаних джерел:}

1. Butlin J. Our common future. By World commission on environment and development. London : Oxford University Press, 1987. P. 383.

2. Аналіз сталого розвитку - глобальний і регіональний контексти. Міжнар. рада 3 науки (ISC) та ін.; наук. кер. проекту М. З. Згуровський. Київ : КПІ ім. Ігоря Сікорського, 2019. 112 с.

3. Бурда А. І. Оцінювання потенціалу сталого розвитку промислових підприємств : автореф. дис. ... канд. екон. наук. Київ, 2008. 18 c.

4. Бурик 3. Трактування сутності понять: сталий розвиток, державне управління, державне регулювання, державне регулювання сталого розвитку. Теоретичні та прикладні питання державотворення. 2017. Вип. 21. С. 10-19.

5. Основи стійкого розвитку : навчальний посібник / За заг. ред. Л. Г. Мельника. Суми : ВТД «Університетська книга», 2005. 654 с.

6. Офіційний сайт Державної служби статистики України. URL: http://www.ukrstat.gov.ua/

7. Скоробогатова Н. Є. Особливості контролінгу в сучасних умовах господарювання. Економічний вісник НТУУ «КПI». 2015. № 12. С. 311-317.

8. Скоробогатова Н. Є. Ліквідність як фактор управління фінансовим розвитком промислових підприємств. Вісник КНУТД. 2012. № 2(64). C. 149-157. URL: https://er.knutd.edu.ua/bitstream/123456789/3562/1/V64_P149-157.pdf

9. Тодорюк С. І. “Сталий розвиток” як економічна категорія. Вісник Хмельнииького наиіонального університету. 2013. № 1. C. 199-202.

10. Торкатюк В. І., Бібік Н. В. Сталий розвиток територій: Основні науково-теоретичні підходи до визначення та сутність поняття. Бізнес-информ. 2009. № 4. С. 127.

\section{References:}

1. Butlin J. (1987), Our common future. By World commission on environment and development. London: Oxford University Press, p. 383.

2. Analysis of sustainable development - global and regional contexts (2019). International Science Council (ISC), etc.; scientific supervisor project M. Z. Zgurovskyi. Kyiv: Igor Sikorsky KPI, 112 p.

3. Burda, A. I. (2008), Estimation of potential of sustainable development of industrial enterprises: author's ref. dis. ... cand. econ. science. Kyiv, 18 p.

4. Buryk, Z. (2017), Interpretation of the essence of concepts: sustainable development, public administration, state regulation, state regulation of sustainable development. Teoretychni ta prykladni pytannia derzhavotvorennia, vol. 21, pp. 10-19.

5. Fundamentals of sustainable development: a textbook (2005), For general. ed. Melnik L. G. Sumy: VTD University Book, 654 p.

6. Official site of the State Statistics Service of Ukraine. URL: http://www.ukrstat.gov.ua/

7. Skorobogatova, N. Ye. (2015), Features of controlling in modern business conditions. Economic Bulletin of NTUU "KPI", no. 12 , pp. 311-317.

8. Skorobogatova, N. Ye. (2012), Liquidity as a factor in managing the financial development of industrial enterprises. Bulletin of KNUTD, no. 2(64), pp. 149-157. URL: https://er.knutd.edu.ua/bitstream/123456789/3562/1/V64_P149-157.pdf

9. Todoryuk, S. I. (2013), "Sustainable development" as an economic category. Bulletin of Khmelnytsky National University, no. 1, pp. 199-202.

10. Torkatyuk, V. I. and Bibik N. V. (2009), Sustainable development of territories: Basic scientific and theoretical approaches to the definition and essence of the concept. Business inform, no. 4, pp. 127-135. 
Skorobogatova Natalia

National Technical University of Ukraine «Igor Sikorsky Kyiv Polytechnic Institute»

\section{EVALUATION OF THE SUSTAINABILITY OF ENTERPRISE DEVELOPMENT IN THE CONDITIONS OF ECONOMIC UNSTABILITY}

The analysis of theoretical approaches to defining the essence of the concept of sustainable development of various economic entities was made in the article. The essential features of sustainable development have been systematized by the author. Also, as a result of the analysis of literary sources, fundamental differences were identified between the theoretical concepts of sustainable (stable) and sustainable development of society. Based on the analysis of the data of the State Statistics Service of Ukraine, the dynamics of changes in the structure of assets of Ukrainian enterprises was analysed. Graphs highlighting the features of the formation of assets and liabilities of large, medium and small enterprises were built. Based on the analysis of statistical data on the sources of formation of economic assets of enterprises during 2013 - 2019, imbalances were identified that negatively affect the efficiency of their activities. In particular, the high degree of dependence of enterprises on external sources of financing leads to a steady trend of decreasing and lack of working capital to support the sustainable development of the enterprise in the long term. This problem is especially evident in medium-sized Ukrainian enterprises. At the same time, the paradox of the functioning of domestic business has been proven, namely: with an insufficient amount of working capital, Ukrainian enterprises demonstrate an increase in the level of profitability of both operating and all activities. Correlation analysis of statistical data confirmed the presence of a direct relationship between the volume of capital investments of enterprises and the level of their profitability. However, as a result of the correlation analysis, an inverse relationship was found between the amount of working capital and the amount of capital investment. The dependencies identified in this way made it possible to form the thesis about the presence of a systemic problem in enterprise management-an imbalance in the management of accounts receivable and payable. In an unstable economy, this can lead to a general crisis due to massive insolvency of enterprises. In order to prevent such a situation, a number of measures have been proposed to ensure sustainable development of enterprises by managing their accounts payable and receivable. In particular, the author proposed the introduction of a controlling system at enterprises. First of all, this concerns the system of controlling funds, which was proposed by the author. We believe that this will improve the efficiency of enterprises and at the same time reduce the risk of insolvency, which is especially important in conditions of economic instability.

Key words: sustainable development, economic instability, profitability, investment, profit, liquidity.

JEL classification: D21, D80, E22, O30 